Request for an Opinion

\author{
Correspondence \\ D. H. Lambert \\ lambert@maine.edu
}

\section{Recommendation for the conservation of the name Streptomyces scabies. Request for an Opinion}

\author{
D. H. Lambert, ${ }^{1}$ R. Loria, ${ }^{2}$ D. P. Labeda ${ }^{3}$ and G. S. Saddler ${ }^{4}$ \\ ${ }^{1}$ Dept of Plant, Soil and Environmental Sciences, University of Maine, Orono, ME 04469, USA \\ ${ }^{2}$ Department of Plant Pathology, Cornell University, Ithaca, NY 14853, USA \\ ${ }^{3}$ USDA ARS, National Center for Agricultural Utilization Research, Peoria, IL 61604, USA \\ ${ }^{4}$ Scottish Agricultural Science Agency, Edinburgh, UK
}

\begin{abstract}
The primary streptomycete inciting common scab of potato was first legitimately described by Thaxter in 1892 as 'Oospora scabies', preserving the spelling of an epithet in use since 1846. The name Streptomyces scabies, dating to 1948, was revived in 1989, but changed to Streptomyces scabiei in 1997 to follow grammatical convention. Considering the long-established use and general recognition of 'scabies', it is proposed that the original epithet be conserved.
\end{abstract}

The species epithet of Streptomyces scabies and the names of 23 other species were corrected by Trüper \& de' Clari (1997) to conform to Rule 12c of the International Code of Nomenclature of Bacteria (Lapage et al., 1992) regarding the formation of species names as nouns 'in apposition'. Subsequently, Euzéby (1998) emphasized the competing importance of Principle 1 of the Bacteriological Code, which stresses stability of names, and proposed an amendment to Rule 61 that such changes should be made conservatively, especially if they are substantial or if the original name is cited in the Approved Lists of Bacterial Names (Skerman et al., 1980). Euzéby (1998) also recommended conserving names that had been used for many years and those whose change would create confusion and not be widely supported. Both of these proposals were accepted as amendments of Rule 61 by the Judicial Commission of the International Committee on Systematic Bacteriology (ICSB) (De Vos \& Trüper, 2000) and formally accepted by a vote of the plenary of the ICSB (Labeda, 2000) during the IXth International IUMS Congress on Bacteriology and Applied Microbiology.

We wish to recommend the conservation of the original species name Streptomyces scabies, over Streptomyces scabiei (Trüper \& de' Clari, 1997). Streptomyces scabies was excluded from the Approved Lists of Names in 1980 because its designated type strain and certain other reference strains did not correspond to the species description of Waksman \& Henrici (1948). The species name was validly published in 1989 as Streptomyces scabies (ex Thaxter 1891) Lambert and Loria 1989.

The species epithet scabies, and none other, has been used with progressively revised genera for over a century to refer to the primary pathogen causing potato scab. These names include 'Oomyces scabies' (Thaxter, 1892), 'Actinomyces scabies' (Güssow, 1914) and Streptomyces scabies
(Waksman \& Henrici, 1948; Lambert \& Loria, 1989). The usage originated with 'Tubercinia scabies' (Berkeley, 1846) and 'Sorosporium scabies' (Fisher von Waldheim, 1877), whose authors were describing pathogens causing powdery scab or smut rather than common scab (Thaxter, 1891). Lambert \& Loria (1989) specifically chose this epithet to formally restore the exact name in universal use and did not consider the appropriate Latin case. Thaxter (1892), the first to isolate the organism, did not explain the choice of scabies, and presumably continued Berkeley's convention. The corrected epithet scabiei (Trüper \& de' Clari, 1997) has not achieved widespread recognition and common use, particularly in plant pathology, and is little used in the literature outside of microbial systematics. For example, the term Streptomyces scabies returns 130 post1999 references on the database BIOSIS, while Streptomyces scabiei returns only 21 , and a similar Google search returns 69500 hits for Streptomyces scabies and only 9830 for Streptomyces scabiei. The name change may have corrected a grammatical error, but has caused substantial confusion among many in the agricultural and scientific community as well as complicating the ability to search literature databases for current as well as older literature on this plant pathogen. We would therefore suggest that it would be of greater benefit to agriculture and science that the original species name Streptomyces scabies (ex Thaxter 1891) Lambert and Loria 1989 be conserved.

\section{References}

Berkeley, M. J. (1846). Observations, botanical and physiological, on the potato murrain. J Hortic Soc Lond 1, 9-34 (as cited in Thaxter, 1891).

De Vos, P. \& Trüper, H. G. (2000). Judicial Commission of the International Committee on Systematic Bacteriology. IXth International (IUMS) Congress of Bacteriology and Applied 
Microbiology. Minutes of the meetings, 14, 15 and 18 August 1999, Sydney, Australia. Int J Syst Evol Microbiol 50, 2239-2244.

Euzéby, J. P. (1998). Proposal to amend Rule 61 of the International Code of Nomenclature of Bacteria (1990 revision). Int J Syst Bacteriol 48, 611-612.

Fisher von Waldheim, A. (1877). Aperçu Systematique des Ustilagineés leurs Plantes Nourricières et la Localization de leur Spores, p. 33. Paris.

Güssow, H. T. (1914). The systematic position of the organism of the common potato scab. Science 39, 431-432.

Labeda, D. P. (2000). International Committee on Systematic Bacteriology. IXth International (IUMS) Congress of Bacteriology and Applied Microbiology. Minutes of the meetings, 14 and 17 August 1999, Sydney, Australia. Int J Syst Evol Microbiol 50, 2245-2247.

Lambert, D. H. \& Loria, R. (1989). Streptomyces scabies sp. nov., nom. rev. Int J Syst Bacteriol 39, 387-392.

Lapage, S. P., Sneath, P. H. A., Lessel, E. F., Skerman, V. B. D., Seliger, H. P. R. \& Clark, W. A. (editors) (1992). International Code of
Nomenclature of Bacteria (1990 Revision). Bacteriological Code. Washington, DC: American Society for Microbiology.

Skerman, V. B. D., McGowan, V. \& Sneath, P. H. A. (editors) (1980). Approved Lists of Bacterial Names. Int J Syst Bacteriol 30, 225420.

Thaxter, R. (1891). The potato scab. Conn Agric Expt Stn Rept 1890, 81-95.

Thaxter, R. (1892). Potato scab. Conn Agric Expt Stn Rept 1891, 153160.

Trüper, H.G. \& de' Clari, L. (1997). Taxonomic note: necessary correction of specific epithets formed as substantives (nouns) "in apposition". Int J Syst Bacteriol 47, 908-909.

Waksman, S. A. \& Henrici, A. T. (1948). Family II. Actinomycetaceae Buchanan and family Streptomycetaceae Waksman and Henrici. In Bergey's Manual of Determinative Microbiology, 6th edn, pp. 892-980. Edited by R. S. Breed, E. G. D. Murray \& A. P. Hitchens. Baltimore: Williams \& Wilkins. 